\title{
Ekmeklik Buğday Çeşitlerinin Erzurum Kuru Tarım Koşullarına Adaptasyonu
}

\author{
Selçuk KODAZ ${ }^{1} \quad$ Murat AYDIN $^{2} \quad$ Ali ÖZTÜRK $^{1}$ \\ ${ }^{1}$ Atatürk Üniversitesi Ziraat Fakültesi Tarla Bitkileri Bölümü, 25240 Erzurum \\ ${ }^{2}$ Atatürk Üniversitesi Ziraat Fakültesi Tarımsal Biyoteknoloji Bölümü, 25240 Erzurum \\ $\bowtie$ : selcuk.kodaz@atauni.edu.tr
}

Geliş (Received): 04.11.2017

Kabul (Accepted): 15.12.2017

\begin{abstract}
ÖZET: Erzurum yöresinde buğday tarımını daha verimli kılmak için son yıllarda sayıları artan çeşitlerden yöreye uyumlu yüksek verimli olanlarının belirlenmesi ve ekiminin yaygınlaştırılması gerekmektedir. Bu çalışma, Atatürk Üniversitesi Ziraat Fakültesi Tarımsal Araştırma ve Yayım Merkezi Müdürlüğü 4 numaralı deneme alanında 201112 ve 2012-13 ürün yıllarında yürütülmüş, 25 ekmeklik buğday çeşidinin Erzurum kuru tarım koşullarına adaptasyonu araştırılmıştır. Araştırmada çeşitlerin vejetatif periyot, tane dolum süresi, bitki boyu, m2'deki başak sayısı, başaktaki tane sayısı, 1000 tane ağırlığı, tane verimi, hasat indeksi ve ham protein oranları incelenmiştir. Ürün yıllarının ortalamasına göre çeşitlerin vejetatif periyodu 12.5-19.0 gün, tane dolum süresi 27.0-36.6 gün, bitki boyu 72.9-110 cm, m2'deki başak sayısı 445.8-709.2, başaktaki tane sayısı 21.3-47.4, 1000 tane ağırlı̆̆ 37.3-46.4 g, tane verimi $339.7-519.2 \mathrm{~kg} / \mathrm{da}$, hasat indeksi \% 30.6-40.4, ham protein oranı ise \%11.80-14.68 arasında değişim göstermiştir. İncelenen karakterler yönünden çeşitler arasında önemli farklar bulunmuştur. En yüksek tane verimine Nacibey (519.2 kg/da) çeşidi sahip olmuş, bu çeşidi Atay 85 (501.1 kg/da) ve Aytın 98 (484.2 kg/da) çeşitleri takip etmiştir. En yüksek ham protein oranı Kırik (\%14.68) çeşidinden elde edilmiş, bu çeşidi Aldane (\%14.05) ve Tosunbey (\%13.35) çeşitleri izlemiştir. Nispeten yüksek tane verimine ve protein oranına sahip Sönmez 2001, Tosunbey ve İzgi 2001 çeşitlerinin Erzurum yöresi için ümitvar çeşitler oldukları sonucuna varılmıştır.

Anahtar Kelimeler: buğday, adaptasyon, tane verimi, çeşit
\end{abstract}

\section{Adaptation of Bread Wheat Varieties to Erzurum Dry Agricultural Conditions}

ABSTRACT: In order to make wheat farming more efficient in Erzurum region, it is necessary to identify and increase the number of locally grown high yielding cultivars. This study was carried out at resarch field \#4 of Atatürk University Agricultural Research and Extension Center in 2011-12 and 2012-13 years. Adaptability of 25 bread wheat cultivars under erzurum dryland farming condition was evaluated. In this experiment on average of cropping seasons, vegetative period, grain filling period, plant height, spike number per m2, grain number per spike, 1000 grain weight, grain yield, harvest index and crude protein ratios of the cultivars ranged between 12.5 and 19.0 days, 27.0 and 36.6 days, 72.9 and $110.0 \mathrm{~cm}, 445.8$ and $709.2,21.3$ and 47.4, 37.3 and $46.4 \mathrm{~g}, 339.7$ and 519.2 $\mathrm{kg} / \mathrm{da}, 30.6 \%$ and $40.4 \%$ and $11.8 \%$ and $14.68 \%$ respectively. The results revealed that differences among the cultivars for all parameters were significant. The highest grain yield obtained from cv. Nacibey $(519.2 \mathrm{~kg} / \mathrm{da})$ followed by the cv. Atay $85(501.1 \mathrm{~kg} / \mathrm{da})$ and Aytın $98(484.2 \mathrm{~kg} / \mathrm{da})$. The cv. Kirik (14.68\%) had highest crude protein content followed by the cv. Aldane (\%14.05) and the cv. Tosunbey (\%13.35). The result of this research demonestreated that the cv. Sönmez 2001, cv. Tosunbey and cv. İzgi 2001 could be suggested for this region because of their higher yields and crude protein ratio.

Key words: Wheat, adaptation, grain yield, cultivars.

\section{GİRIŞ}

Buğday, ülkemizde 7.6 milyon ha ekim alanı ve 20.6 milyon ton üretim ile kültür bitkileri içerisinde ilk sırada yer alan stratejik bir bitkidir. (Anon., 2016). Buğday, Erzurum ilinde tarımı yapılan kültür bitkileri içerisinde de önemli bir yere sahiptir. Erzurum ilindeki ekili tarla arazisi 346075 ha, buğday ekim alanı 113972 ha, buğday verimi ise $173 \mathrm{~kg} / \mathrm{da}$ 'dır (Anon., 2016). İldeki verimi, Türkiye ortalamasının (266 kg/da) çok altındadır.

Buğday tarımını daha verimli kılmak için son yıllarda sayıları artan çeşitlerinden yöreye uyumlu ve yüksek verimli olanlarının belirlenmesi ve ekim alanlarının yaygınlaştırılması çok önemlidir. Daha önce konu ile ilgili olarak Akkaya ve Akten (1988), Erzurum kuru tarım koşullarında 5 kışlık buğday genotipinin adaptasyonunu araştırmış ve Yayla 305 çeşidini yöre için önermiştir. Çağlar ve Akten (1994), 15 buğday genotipini kullanarak yaptıkları çalışmada genotiplerin bitki boylarını $60.4-84.8 \mathrm{~cm}$, tane verimlerini $177.2-$ $267.4 \mathrm{~kg} / \mathrm{da}$, tane protein oranlarını ise \%10.9-13.7 arasında belirlemişlerdir. Çağlar ve ark. (2006), 25 ekmeklik buğday çeşidinin Erzurum koşullarına adaptasyonu araştırmışlar, $\mathrm{m}^{2}$, deki başak sayısının 373.8-604.4, başaktaki tane sayısının 19.9-30.4, bin tane ağırlığının 34.1-42.5 g, tane veriminin 302.4-460.7 $\mathrm{kg} / \mathrm{da}$, ham protein oranının ise \%11.2-13.5 arasında değiştiğini bildirmişlerdir. En yüksek $\mathrm{m}^{2}$ 'deki başak sayıs1 ve tane verimine Doğu 88 , en yüksek ham protein oranına ise Alparslan ve Türkmen çeşitlerinin sahip olduğunu belirlemişlerdir. Özen ve Akman (2015), Yozgat kuru tarım koşullarında 14 ekmeklik buğday çeşidinde $\mathrm{m}^{2}$ 'deki başak sayısının 423-492, başaktaki tane sayısının 22-46, bin tane ağırlığının 33-44 g, tane veriminin $427-639 \mathrm{~kg} / \mathrm{da}$, ham protein oranının ise \% 813 arasında değiştiğini bildirmişler, yüksek verim ve 
kalite özellikleri nedeniyle Karahan 99, Bayraktar 2000 ve Dağdaş 94 çeşitlerini önermişlerdir. Doğan ve Kendal (2013), 25 ekmeklik buğday genotipinin verim ve kalite yönünden Diyarbakır ekolojik koşullarındaki performanslarını belirlemek için yürüttükleri çalışmada $9,17,18,19$ ve 24 numaralı genotiplerin ümitvar olduklarını belirlemişlerdir. Naneli ve ark. (2015) tarafindan Tokat-Kazova koşullarında 25 ekmeklik buğday çeşidini ile yürütülen çalışmada, en yüksek tane verimine Nacibey, en yüksek protein oranına ise Aldane, Akar ve Flamura-85 çeşitlerinin sahip olduğu belirlenmiştir.

Islah edilen çeşit sayısındaki artış, yeni çeşitleri de kapsayacak şekilde adaptasyon çalışmalarının belirli aralıklarla tekrarlanması gerektirmektedir. $\mathrm{Bu}$ çalışma, Erzurum yöresinde buğday tarımını daha verimli kılmak amacıyla yürütülmüş, 25 ekmeklik buğday çeşidinin yöre koşullarına uygunlukları ve bazı tarımsal özellikleri incelenmiştir.

\section{MATERYAL ve YÖNTEM}

$\mathrm{Bu}$ araştırma, Atatürk Üniversitesi Ziraat Fakültesi Tarımsal Araştırma ve Yayım Merkezi Müdürlüğü 4 numaralı deneme alanında 2011-12 ve 2012-2013 ürün yıllarında ve kuru tarım koşullarında yürütülmüştür. Denemede toplam 25 ekmeklik buğday çeşidi kullanılmış, bu çeşitlere ait bilgiler Tablo 1'de verilmiştir.

Araştırmanın yürütüldüğü 2011-12 ve 2012-13 ürün yıllarında toplam yağış miktarı sırasıyla 250.5 ve 311.1 mm, ortalama sicaklık ise 3.9 ve $6.4{ }^{\circ} \mathrm{C}$ olmuştur. Ürün yıllarında uzun yıllar ortalamasına göre $(398.8 \mathrm{~mm})$ daha az yağış düşmüştür. Ortalama sıcaklık uzun yıllar ortalamasına göre $\left(5.0^{\circ} \mathrm{C}\right)$ birinci yılda daha düşük, ikinci ürün yılında ise daha yüksek olmuştur. Deneme yeri topraklarının killi-tınlı, organik madde oranının az, reaksiyonu hafif alkali, az kireçli, fosfor yönünden orta, potasyum yönünden ise çok zengin olduğu belirlenmiştir.

Araştırma, tesadüf blokları deneme planına göre 3 tekrarlı yürütülmüştür. Çeşitler standart yetiştirme teknikleri uygulanarak bir önceki yıl nadasa bırakılmış, toprak hazırlığ 1 yapılmış tarlaya $\mathrm{m}^{2}$ ye 475 canlı tohum olacak şekilde baskılı parsel mibzeri ile birinci y1l 21 Eylül 2011, ikinci yıl ise 4 Eylül 2012 tarihinde ekilmiştir. Her parsel $6.0 \mathrm{~m}$ uzunluğunda ve $1.2 \mathrm{~m}$ genişliğinde, $20 \mathrm{~cm}$ aralıklı 6 bitki sırasından oluşmuştur. Parseller $6 \mathrm{~kg} / \mathrm{da} \mathrm{N}$ ve $5 \mathrm{~kg} / \mathrm{da} \mathrm{P}_{2} \mathrm{O}_{5}$ olacak şekilde gübrelenmiş, fosforun tamamı ile azotun yarısı ekimle birlikte, azotun diğer yarısı ise sapa kalkma başlangıcında uygulanmıştır. Yabancı otlar elle kontrol edilmiş ve bitkiler tam olgunluk döneminde orakla hasat edilip tarlada 2-3 gün kurutulduktan sonra harman edilmiş̧ir. Çeşitlerin vejetatif periyot (1 Haziran=1), tane dolum süresi, bitki boyu, $\mathrm{m}^{2}$ deki başak sayısı, başaktaki tane sayısı, bin tane ağırlığı, tane verimi, hasat indeksi ve ham protein oranları belirlenmiştir.

Elde edilen verilerin varyans analizi deneme planına uygun olarak SAS GLM (SAS Inst., Cary, NC) bilgisayar programı ile yapılmış, ortalamaların karşılaştırılmasında Duncan çoklu karşılaştırma testi kullanılmıştır.

Tablo 1. Araştırmada kullanılan ekmeklik buğday çeşitlerine ait bazı bilgiler

\begin{tabular}{|c|c|c|c|}
\hline Çeşit adı & Çeşit sahibi kuruluş & Gelişme tabiatı & Tane rengi \\
\hline Aldane & Trakya Tarımsal Arş. Enst. & Alternatif & Kirmizi \\
\hline Altay 2000 & Anadolu Tarımsal Arş. Enst. & K1şlik & Beyaz \\
\hline Atay 85 & Anadolu Tar. Araş. Enst. & Kışlik & Beyaz \\
\hline Atli 2002 & Tarla Bitkileri Merkez Arş. Enst. & Alternatif & Kirmız1 \\
\hline Aytın 98 & Anadolu Tarımsal Arş. Enst. & Kişlık & Beyaz \\
\hline Bağc1 2002 & Bahri Dağdaş Uluslararası Tar. Arş. Enst. & Alternatif & Kirmiz1 \\
\hline Bereket & Trakya Tarımsal Arş. Enst. & Kişlik & Kirmız1 \\
\hline Çetinel 2000 & Anadolu Tarımsal Arş. Enst. & Kışlik & Beyaz \\
\hline Dağdaş 94 & Bahri Dağdaş Uluslararası Tarımsal Arş. Enst. & Alternatif & Beyaz \\
\hline Doğu 88 & Doğu Anadolu Tar. Araş. Enst. & Kişlık & Kirmız1 \\
\hline ES 26 & Anadolu Tarımsal Arş. Enst. & Kişlık & Beyaz \\
\hline Gerek 79 & Anadolu Tar. Araş. Enst. & Kışlık & Beyaz \\
\hline Harmankaya 99 & Anadolu Tarımsal Arş. Ens. & Kişlık & Kirmız1 \\
\hline İzgi 2001 & Anadolu Tarımsal Arş. Enst. & Kişlik & Beyaz \\
\hline Karahan 99 & Bahri Dağdaş Uluslararası Tarımsal Arş. Enst. & Kişlik & Beyaz \\
\hline Kırik & Doğu Anadolu Tarımsal Arş. Enst. & Alternatif & Beyaz \\
\hline Müfitbey & Anadolu Tarımsal Arş. Enst. & Kişlik & Beyaz \\
\hline Nacibey & Anadolu Tarımsal Arş. Enst. & Kişlik & Kirmız1 \\
\hline Palandöken 97 & Doğu Anadolu Tarımsal Arş. Enst. & Kışlik & Beyaz \\
\hline Prostor & Trakya Tarımsal Arş. Enst. & Kişlık & Kirmız1 \\
\hline Soyer 02 & Anadolu Tarımsal Arş. Enst. & Kışlık & Beyaz \\
\hline Sönmez 2001 & Anadolu Tarımsal Arş. Enst. & Kişlık & Kirmız1 \\
\hline Süzen 97 & Anadolu Tarımsal Arş. Enst. & Kişlık & Beyaz \\
\hline Tosunbey & Tarla Bitkileri Merkez Arş. Enst. & Kişlık & Beyaz \\
\hline Zencirci 2002 & Tarla Bitkileri Merkez Arş. Enst. & Alternatif & Beyaz \\
\hline
\end{tabular}




\section{BULGULAR ve TARTIŞMA}

Ürün yıllarının ortalaması olarak buğday çeşitlerinin vejetatif periyot, tane dolum süresi, bitki boyu, $\mathrm{m}^{2}$ 'deki başak sayısı, başaktaki tane sayısı, bin tane ağırlı̆ı̆ı, tane verimi, hasat indeksi ve ham protein oranları Tablo 2'de verilmiştir. İncelenen karakterler yönünden çeşitler arasındaki farklar, ürün yıllarının başaktaki tane sayısı hariç diğer karakterlere etkisi ve incelenen karakterler yönünden çeşit $\mathrm{x}$ yıl interaksiyonları önemli bulunmuştur.

\section{Vejetatif Periyot ve Tane Dolum Süresi}

Çeşitlerin ortalaması olarak 2011-12 ve 2012-13 ürün yıllarına ait vejetatif periyotlar sirasiyla 18.5 ve 14.8 gün, tane dolum süreleri ise 35.3 ve 28.6 gün olmuştur. Buğday çeşitlerinin vejetatif periyot değerleri
12.5-19.0 gün arasında değişmiş ve en kısa vejetatif periyot Aldane ve Bereket çeşitlerinde gözlenmiştir (Tablo 2). En uzun vejetatif periyot değerine Atay 85 çeşidi sahip olmuş, bu çeşidi Kırik, Çetinel 2000 ve Soyer 02 çeşitleri izlemiştir. Çağlar ve ark. (2006), ekmeklik buğday çeşitleri arasında vejetatif periyot bakımından önemli farklar bulunduğuna dikkat çekmişler, vejetatif periyodun 14.1-22.5 gün arasında değiştiğini belirlemişlerdir. Ekmeklik buğdaylarda vejetatif periyot yönünden genotipler arasında önemli farklar bulunduğunu belirten Wiegan ve ark. (1981), çiçeklenme tarihleri arasında 8-11 gün, Öztürk ve Akkaya (1996) ise 6-9 fark bulmuşlardır. Çeşitlerin tane dolum süreleri 27.0-36.7 gün arasında değişmiştir (Tablo 2).

Tablo 2. Ekmeklik buğday çeşitlerinin vejetatif periyot, tane dolum süresi, bitki boyu, $\mathrm{m}^{2}$ 'deki başak sayısı, başaktaki tane sayısı, bin tane ağırlığı, tane verimi, hasat indeksi ve ham protein oranları ${ }^{1}$

\begin{tabular}{|c|c|c|c|c|c|c|c|c|c|}
\hline Çeşit İsmi & $\begin{array}{c}\text { Vefetatif } \\
\text { periyot } \\
\text { (gün) }\end{array}$ & $\begin{array}{l}\text { Tane } \\
\text { dolum } \\
\text { süresi } \\
\text { (gün) }\end{array}$ & $\begin{array}{l}\text { Bitki } \\
\text { boyu } \\
(\mathrm{cm})\end{array}$ & $\begin{array}{l}\mathrm{m}^{2} \text { 'deki } \\
\text { başak } \\
\text { say1s1 }\end{array}$ & $\begin{array}{c}\text { Başaktaki } \\
\text { tane } \\
\text { sayıs1 }\end{array}$ & $\begin{array}{c}\text { Bin } \\
\text { tane } \\
\text { ăgrrlığg } \\
\text { (g) }\end{array}$ & $\begin{array}{c}\text { Tane } \\
\text { verimi } \\
(\mathrm{kg} / \mathrm{da})\end{array}$ & $\begin{array}{c}\text { Hasat } \\
\text { indeksi } \\
(\%)\end{array}$ & $\begin{array}{c}\text { Ham } \\
\text { protein } \\
\text { oranı } \\
(\%)\end{array}$ \\
\hline Aldane & $12.5^{\mathrm{m}}$ & $33.9^{\text {bcd }}$ & $85.2^{\mathrm{mn}}$ & $565.8^{\mathrm{gh}}$ & $32.8^{\mathrm{f}-1}$ & $44.3^{\text {bcd }}$ & $406.1^{1 \mathrm{j}}$ & $33.4^{\mathrm{jkl}}$ & $14.05^{\mathrm{b}}$ \\
\hline Altay 2000 & $15.8^{\mathrm{hij}}$ & $36.6^{\mathrm{a}}$ & $107.4^{\mathrm{b}}$ & $445.8^{\mathrm{k}}$ & $38.6^{\mathrm{b}-\mathrm{h}}$ & $41.3^{\mathrm{h}-\mathrm{k}}$ & $448.8^{\text {ef }}$ & $31.9^{\mathrm{lm}}$ & $12.30^{1}$ \\
\hline Atay 85 & $19.0^{\mathrm{a}}$ & $30.2^{\mathrm{ht}}$ & $86.3^{\mathrm{m}}$ & $627.5^{\text {cde }}$ & $41.9^{a-e}$ & $40.2^{\mathrm{kl}}$ & $501.1^{\mathrm{ab}}$ & $35.8^{\mathrm{d}-\mathrm{h}}$ & $11.95^{\mathrm{m}}$ \\
\hline Atl1 2002 & $17.5^{\text {cde }}$ & $35.0^{\mathrm{ab}}$ & $102.3^{\mathrm{c}}$ & $633.3^{\mathrm{bcd}}$ & $28.8^{\mathrm{jk}}$ & $45.3^{\mathrm{abc}}$ & $432.3^{\text {fgh }}$ & $32.9^{\mathrm{kl}}$ & $12.45^{\mathrm{j}}$ \\
\hline Aytın 98 & $17.7^{\mathrm{b}-\mathrm{e}}$ & $32.7^{\mathrm{c}-\mathrm{f}}$ & $84.3^{\text {no }}$ & $650.8^{\mathrm{bc}}$ & $33.5^{\mathrm{f}-1}$ & $41.3^{\mathrm{h}-\mathrm{k}}$ & $484.2^{\mathrm{bc}}$ & $37.4^{\mathrm{bf}}$ & $12.40^{\mathrm{j} k}$ \\
\hline Bağc1 2002 & $16.2^{\text {hij }}$ & $33.3^{\mathrm{b}-\mathrm{e}}$ & $85.9^{\mathrm{mn}}$ & $651.7^{\mathrm{bc}}$ & $39.5^{\mathrm{b}-\mathrm{g}}$ & $37.5^{\mathrm{n}}$ & $397.2^{1 \mathrm{j}}$ & $38.0^{\mathrm{bc}}$ & $12.70^{\mathrm{g}}$ \\
\hline Bereket & $14.0^{1}$ & $36.3^{\mathrm{a}}$ & $78.2^{\mathrm{q}}$ & $504.2^{1}$ & $41.6^{\mathrm{a}-\mathrm{e}}$ & $40.8^{-1-1}$ & $339.7^{\mathrm{n}}$ & $39.2^{\mathrm{ab}}$ & $11.85^{\mathrm{n}}$ \\
\hline Çetinel 2000 & $18.2^{\mathrm{abc}}$ & $32.6^{\mathrm{c}-\mathrm{f}}$ & $81.7^{\mathrm{p}}$ & $438.3^{\mathrm{k}}$ & $41.5^{\mathrm{a}-\mathrm{e}}$ & $42.5^{\mathrm{e}-\mathrm{h}}$ & $350.2^{\mathrm{mn}}$ & $36.6^{\mathrm{c}-\mathrm{g}}$ & $12.35^{\mathrm{kl}}$ \\
\hline Dağdaş 94 & $17.5^{\text {cde }}$ & $30.5^{\mathrm{gh}}$ & $99.4^{\mathrm{d}}$ & $599.2^{\text {ef }}$ & $31.6^{\mathrm{h}-1}$ & $42.0^{\text {ght }}$ & $370.7^{\mathrm{klm}}$ & $30.6^{\mathrm{m}}$ & $12.50^{\mathrm{ht}}$ \\
\hline Doğu 88 & $17.5^{\text {cde }}$ & $32.2^{\mathrm{efg}}$ & $110.0^{\mathrm{a}}$ & $638.3^{\mathrm{bc}}$ & $21.9^{\mathrm{jk}}$ & $39.3^{\mathrm{lm}}$ & $410.2^{g-j}$ & $32.0^{\mathrm{klm}}$ & $13.00^{\mathrm{f}}$ \\
\hline ES 26 & $17.2^{\operatorname{def}}$ & $34.3^{\mathrm{bc}}$ & $92.1^{\mathrm{jk}}$ & $709.2^{\mathrm{a}}$ & $33.3^{\mathrm{f}-1}$ & $37.3^{\mathrm{n}}$ & $433.0^{\mathrm{fg}}$ & $35.7^{\mathrm{e}-\mathrm{h}}$ & $12.95^{\mathrm{f}}$ \\
\hline Gerek 79 & $18.2^{\mathrm{abc}}$ & $29.6^{\mathrm{h}-\mathrm{k}}$ & $94.7^{\mathrm{hr}}$ & $661.7^{\mathrm{b}}$ & $31.3^{\mathrm{h}}$ & $38.0^{\mathrm{mn}}$ & $407.8^{\text {hij }}$ & $35.5^{\mathrm{f}_{-1}}$ & $12.70^{\mathrm{g}}$ \\
\hline Harmankaya 99 & $14.5^{\mathrm{kl}}$ & $36.7^{\mathrm{a}}$ & $72.9^{\mathrm{r}}$ & 489.2 & $45.5^{\mathrm{ab}}$ & $43.9^{\text {cde }}$ & $459.7^{\text {cde }}$ & $40.3^{\mathrm{a}}$ & $11.85^{\mathrm{n}}$ \\
\hline İzgi 2001 & $17.0^{\mathrm{efg}}$ & $29.7^{\text {hij }}$ & $96.3^{\text {fgh }}$ & $624.2^{\text {cde }}$ & $36.3^{\mathrm{c}-1}$ & $41.8^{\mathrm{hij}}$ & $462.8^{\text {cde }}$ & $37.2^{\mathrm{b}-\mathrm{g}}$ & $13.20^{\mathrm{d}}$ \\
\hline Karahan 99 & $17.3^{\mathrm{c}-\mathrm{f}}$ & $31.2^{\text {fgh }}$ & $97.6^{\mathrm{ef}}$ & $553.3^{\mathrm{h}}$ & $32.6^{\text {ght }}$ & $42.3^{\mathrm{e}-1}$ & $418.6^{\mathrm{gh} 1}$ & $33.5^{1-1}$ & $13.20^{\mathrm{d}}$ \\
\hline Kırik & $18.5^{\mathrm{ab}}$ & $27.9^{\mathrm{kl}}$ & $108.4^{\mathrm{ab}}$ & $604.2^{\mathrm{def}}$ & $21.3^{\mathrm{k}}$ & $39.3^{\mathrm{Im}}$ & $388.4^{\mathrm{jk}}$ & $31.5^{\mathrm{lm}}$ & $14.68^{\mathrm{a}}$ \\
\hline Müfitbey & $18.0^{\text {bcd }}$ & $28.4^{\mathrm{jkl}}$ & $98.0^{\text {def }}$ & $565.0^{\mathrm{gh}}$ & $29.4^{\mathrm{ij}}$ & $46.4^{\mathrm{a}}$ & $460.3^{\text {cde }}$ & $34.0^{\mathrm{h}-\mathrm{k}}$ & $12.45^{\mathrm{j}}$ \\
\hline Nacibey & $17.8^{\mathrm{b}-\mathrm{e}}$ & $27.0^{1}$ & $82.9^{\text {op }}$ & $508.3^{1}$ & $43.6^{\mathrm{abc}}$ & $40.4^{\mathrm{jkl}}$ & $519.2^{\mathrm{a}}$ & $40.4^{\mathrm{a}}$ & $11.80^{\mathrm{n}}$ \\
\hline Palandöken 97 & $15.7^{\mathrm{hij}}$ & $32.5^{\text {def }}$ & $88.4^{1}$ & $600.8^{\text {ef }}$ & $34.3^{-1}$ & $43.9^{\text {cde }}$ & $387.3^{\mathrm{jkl}}$ & $36.9^{c-g}$ & $12.55^{\mathrm{h}}$ \\
\hline Prostor & $16.5^{\mathrm{ggh}}$ & $28.7^{1-1}$ & $91.4^{\mathrm{k}}$ & $496.7^{1}$ & $47.4^{\mathrm{a}}$ & $45.5^{\mathrm{ab}}$ & $347.2^{\mathrm{mn}}$ & $32.4^{\mathrm{klm}}$ & $12.30^{1}$ \\
\hline Soyer 02 & $18.2^{\mathrm{abc}}$ & $28.4^{\mathrm{jkl}}$ & $97.0^{\mathrm{fg}}$ & $485.8^{\mathrm{ij}}$ & $29.0^{\mathrm{j}_{1}}$ & $43.5^{\mathrm{d}-\mathrm{g}}$ & $457.4^{\mathrm{def}}$ & $37.6^{\mathrm{b}-\mathrm{e}}$ & $13.10^{\mathrm{e}}$ \\
\hline Sönmez 2001 & $15.3^{\mathrm{jk}}$ & $32.2^{\mathrm{d}-\mathrm{g}}$ & $95.3^{\text {ght }}$ & $557.5^{\mathrm{h}}$ & $42.4^{a-d}$ & $43.6^{\text {def }}$ & $477.5^{\mathrm{bcd}}$ & $37.8^{\mathrm{bcd}}$ & $13.25^{\mathrm{d}}$ \\
\hline Süzen 97 & $16.5^{\text {fgh }}$ & $32.2^{\mathrm{d}-\mathrm{g}}$ & $93.6^{\mathrm{ij}}$ & $627.5^{\text {cde }}$ & $40.3^{\mathrm{a}-\mathrm{f}}$ & $42.7^{\mathrm{d}-\mathrm{h}}$ & $463.8^{\text {cde }}$ & $35.1^{\mathrm{g}-\mathrm{j}}$ & $12.65^{\mathrm{g}}$ \\
\hline Tosunbey & $15.0^{\mathrm{jk}}$ & $33.8^{\mathrm{b}-\mathrm{e}}$ & $88.7^{1}$ & $456.7^{\mathrm{jk}}$ & $35.9^{\mathrm{d}-1}$ & $38.0^{\mathrm{mn}}$ & $455.0^{\mathrm{def}}$ & $40.2^{\mathrm{a}}$ & $13.35^{\mathrm{c}}$ \\
\hline Zencirci 2002 & $15.7^{\mathrm{hij}}$ & $32.3^{\text {def }}$ & $99.4^{\text {de }}$ & $593.3 \mathrm{fg}$ & $30.7^{1}$ & $42.1^{\mathrm{f}-1}$ & $362.4^{\mathrm{mn}}$ & $32.8^{\mathrm{kl}}$ & $12.70^{\mathrm{g}}$ \\
\hline Ortalama & 16.7 & 31.9 & 92.7 & 571.5 & 35.4 & 41.7 & 425.6 & 35.6 & 12.73 \\
\hline $2011-12$ & 18.5 & 35.3 & 90.2 & 671.7 & 35.1 & 42.0 & 449.4 & 37.5 & 13.75 \\
\hline 2012-13 & 14.8 & 28.6 & 95.2 & 471.4 & 35.7 & 41.5 & 401.9 & 33.7 & 11.71 \\
\hline P değeri (Çeşit) & 0.000 & 0.000 & 0.000 & 0.000 & 0.000 & 0.000 & 0.000 & 0.000 & 0.000 \\
\hline P değeri (Yıl) & 0.000 & 0.000 & 0.000 & 0.000 & 0.42 & 0.008 & 0.000 & 0.000 & 0.000 \\
\hline $\begin{array}{l}\text { P değeri } \\
\text { (ÇeşitxYıl) }\end{array}$ & 0.000 & 0.000 & 0.000 & 0.000 & 0.02 & 0.000 & 0.000 & 0.000 & 0.000 \\
\hline AÖF (Çeşit) & 0.89 & 1.76 & 1.79 & 29.29 & 7.59 & 1.57 & 25.17 & 2.03 & 0.05 \\
\hline AÖF (Y1l) & 0.25 & 0.50 & 0.51 & 8.29 & 2.15 & 0.44 & 7.12 & 0.57 & 0.01 \\
\hline AÖF (ÇeşitxY11) & 1.26 & 2.49 & 2.53 & 41.43 & 10.74 & 2.22 & 35.59 & 2.87 & 0.07 \\
\hline $\mathrm{VK}(\%)$ & 3.53 & 3.64 & 1.27 & 3.38 & 14.15 & 2.48 & 3.90 & 3.77 & 0.25 \\
\hline
\end{tabular}

${ }^{1}$ Aynı harf ile işaretli ortalamalar arasındaki farklar önemsizdir. 


\section{Bitki Boyu ve Metrekaredeki Başak Sayısı}

En uzun tane dolum süresine Harmankaya 99 çeşidi sahip olmuş, bu çeşidi Altay 2000 ve Bereket çeşitleri izlemiştir. En kısa tane dolum süresine ise Nacibey, Müfitbey ve Soyer 02 çeşitleri sahip olmuştur. Çağlar ve ark. (2006), tane dolum süresinin 34.4-39.3 gün arasında değiştiğini bildirmişlerdir. Öztürk ve Akkaya (1996), Erzurum koşullarında yürüttükleri çalışmada ekmeklik buğdayda tane dolum süresini 31.5-38.0 gün arasında belirlemişlerdir. Çeşitlerin ortalaması olarak 2011-12 ve 2012-13 ürün yıllarında bitki boyları sırasıyla 90.2 ve $95.2 \mathrm{~cm}, \mathrm{~m}^{2}$ 'deki başak sayısı ise 971.7 ve 471.4 adet olmuştur (Tablo 2). Buğday çeşitlerinin bitki boyları 72.9-110.0 cm arasında değişmiş, en yüksek bitki boyuna Doğu 88, Kırik ve Altay 2000; en kısa bitki boyuna ise Harmankaya 99, Bereket ve Çetinel 2000 çeşitleri sahip olmuştur. Erzurum koşullarında daha önce yapılan bir çalışmada Çağlar ve ark. (2006), ekmeklik buğday çeşitlerinin bitki boylarının 72.5-99.3 cm arasında değiştiğini bildirmişlerdir. Ekmeklik buğday genotiplerinde bitki boyunun Yozgat ekolojik koşullarında yapılan bir çalışmada 85.5-111.7 cm (Özen ve Akman, 2015), Eskişehir koşullarında 112.3-139 cm (Tunca 2012), Diyarbakır koşullarında ise 83.6-125 cm (Doğan ve Kendal 2012) arasında değiştiği belirlenmiştir. Çeşitlerin $\mathrm{m}^{2}$ 'deki başak sayıları 438.3-709.2 arasında değişmiştir (Tablo 2). Metrekarede en yüksek başak sayısına ES 26 çeşidi sahip olmuş, bunu Gerek 79, Bağc1 2002 ve Aytın 98 çeşitleri izlemiş̧ir. Metrekarede en düşük başak sayısı ise Çetinel 2000, Altay 2000 ve Tosunbey çeşitlerinde belirlenmiştir. Çağlar ve ark. (2006), Erzurum koşullarında $\mathrm{m}^{2}$ 'deki başak sayısının 373.8-604.4 arasında değiştiğini bildirmişlerdir. Özen ve Akman (2015), Yozgat ekolojik koşullarında buğday genotiplerinin $\mathrm{m}^{2}$ deki başak sayısını 423-491 arasında belirlemişlerdir.

\section{Başaktaki Tane Sayısı ve Bin Tane Ağırlı̆ğ}

Çeşitlerin ortalaması olarak 2011-12 ve 2012-13 ürün yılların başaktaki tane sayıları sırasıyla 35.1 ve $35.7,1000$ tane ağırlığı ise 42.0 ve $41.5 \mathrm{~g}$ olmuştur. Ekmeklik buğday çeşitlerinin başaktaki tane sayıları 21.3-47.4 arasında değişmiştir. Prostor çeşidi en yüksek başakta tane sayısına sahip olmuş, bu çeşidi Harmankaya 99 ve Nacibey çeşitleri izlemiştir. Başakta en düşük tane sayısı ise Kirik, Doğu 88 ve Atlı 2002 çeşitlerinden elde edilmiştir. Bu çalışmada elde edilen başaktaki tane sayıları Çağlar ve ark. (2006)'nın elde ettikleri değerlere göre daha yüksektir. Aydoğan ve Soylu (2017), Konya koşullarında 14 ekmeklik buğday çeşidinin başaktaki tane sayılarının 31.2-44.9 arasında değiştiğini bildirmişlerdir. Buğday çeşitlerinin bin tane ağırlıkları 37.3-46.4 g arasında değişmiştir. En yüksek bin tane ağırllğına Müfitbey çeşidi sahip olurken, bunu Atlı 2002 ve Aldane çeşitleri izlemiştir. En düşük bin tane ağırlı̆̆ına ise ES 26 çeşidi sahip olmuş, bu çeşidi Bağc1 2002, Gerek 79 ve Tosunbey çeşitleri izlemiştir. Öztürk ve Akkaya (1996), Erzurum koşullarında başaktaki tane sayısını 20.4-39.3, bin tane ağırlığını ise 37.4-46.8 g arasında bulmuştur. Çağlar ve ark. (2006) tarafindan elde edilen bin tane ağırlıkları (34.1-42.5 g) bu çalışmaya göre daha düşük olmuştur. Konya koşullarında çeşitlerin başaktaki tane sayısının 31.549.4, bin tane ağırlığının ise 32.9-49.4 g arasında olduğu belirlenmiştir (Soylu ve ark., 1999).

\section{Tane Verimi}

Ekmeklik buğday çeşitlerinin ortalamasına göre 2011-12 ve 2012-13 ürün yıllarında tane verimi sırasiyla 449.4 ve $401.9 \mathrm{~kg} / \mathrm{da}$ olmuştur. Ürün yıllarının ortalaması olarak çeşitlerin tane verimleri 339.7-519.2 $\mathrm{kg} / \mathrm{da}$ arasında değişmiştir. En yüksek tane verimi Nacibey çeşidinden elde edilmiş, bu çeşidi Atay 85 ve Sönmez 2001 çeşitleri izlemiştir. En düşük tane verimine Bereket çeşidi sahip olmuş bu çeşidi Prostor ve Çetinel 2002 çeşitleri izlemiş̧ir. Özen ve Akman (2015), Yozgat koşullarında tane veriminin 407.5-638.5 $\mathrm{kg} / \mathrm{da}$ arasında değiştiğini bildirmişlerdir. Çağlar ve ark. (2006), ekmeklik buğday çeşitlerinin tane verimlerinin $302.4-460.7 \mathrm{~kg} / \mathrm{da}$ arasında değiștiğini ve en yüksek tane verimine Doğu 88 çeşidinin sahip olduğunu bildirmişlerdir. Tunca (2012), Eskişehir koşullarında tane veriminin $212-544.9 \mathrm{~kg} / \mathrm{da}$ arasında değiştiğini belirlemişler, en yüksek verimi Ekiz, en düşük verimi ise Doğu- 88 çeşidinden elde etmişlerdir.

\section{Hasat İndeksi ve Ham Protein Oranı}

Çeşitlerin ortalaması olarak hasat indeksi 2011-12 ve 2012-13 ürün y1llarında sırasıyla $\% 37.5$ ve $\% 33.7$ olmuştur. En yüksek hasat indeksine Nacibey çeşidi sahip, bu çeşidi Harmankaya 99 ve Tosunbey çeşitleri izlemiştir. En düşük hasat indeksine ise Dağdaş 94 çeşidi sahip olmuştur. Özen ve Akman (2015), bu araştırma sonuçları ile yakın olarak \% 29.5-38.0 arasında değişen hasat indeksi değerleri elde etmişlerdir. Tunca (2012), yaptığı çalışmada çeşitlerin hasat indekslerinin \% 26.67-46.60 arasında değiştiğini bildirmiştir. Çeşitlerin ortalaması olarak tane protein oranı 2011-12 ve 2012-13 ürün yıllarında sirasıyla \% 13.75 ve \% 11.71 olmuştur. Çeşitlerin ham protein oranları \% 11.80-14.68 arasında değişmiştir. En yüksek tane protein oranı Kırik çeşidinde tespit edilmiş, bu çeşidi Aldane ve Tosunbey çeşitleri izlemiştir. En düşük protein oranları ise Nacibey, Harmankaya 99 ve Bereket çeşitlerinde saptanmıştır. Çağlar ve ark. (2006), ekmeklik buğday çeşitlerinde ham protein oranın \% 11.2 ile 13.5 arasında değiştiğini bildirmişlerdir. Doğan ve Kendal (2013), Diyarbakır koşullarında 25 ekmeklik buğday genotipinde protein oranının \% 9.9-\% 11.9; Aydoğan ve Soylu (2017) ise Konya koşullarında buğday genotiplerinin protein oranlarının \% 11.9-\%14.4 arasında değiştiğini bildirmişlerdir.

\section{SONUÇ}

Erzurum koşullarında bazı ekmeklik buğday çeşitlerinin adaptasyonunun incelendiği bu çalışmada en uzun tane dolum süresi ve hasat indeksine Harmankaya 99 , en yüksek $\mathrm{m}^{2}$ 'deki başak sayısına ES 26 , başakta en yüksek tane sayına Prostor, en yüksek 1000 tane ağırlığına Müfitbey, en yüksek tane verimine Nacibey, en yüksek ham protein oranına ise Kırik çeşidi sahip olmuştur. En yüksek tane verimine sahip Nacibey çeşidi 
en düşük ham protein oranına sahip olmuş, en yüksek ham protein oranına sahip çeşitler düşük tane verimleri ile dikkat çekmişlerdir. Sönmez 2001, Tosunbey ve İzgi 2001 çeşitleri nispeten yüksek ham protein oranları yanında, yörede yaygın olarak ekilen Kırik ve Doğu 88 çeşitlerine göre önemli derecede yüksek tane verimi sağlamışlardır. Bu nedenle Sönmez 2001, Tosunbey ve İzgi 2001 çeşitlerinin Erzurum yöresi için ümitvar çeşitler oldukları sonucunda varılmıştır.

\section{KAYNAKLAR}

Akkaya A, Akten Ş 1988. Susuz Koşullarda Yetiştirilen Bazı Kışlık Buğdayların Toplam Verimi, Tane Verimi ve Hasat İndeksi Üzerine Bir Araştırma. Atatürk Üniv. Zraat Fak. Dergisi, 19: 133-144.

Anomin 2016. Türkiye İstatistik Kurumu İstatistikleri.

Aydoğan S, Soylu S 2017. Ekmeklik Buğday Çeşitlerinin Verim ve Verim Öğeleri ile Bazı Kalite Özelliklerinin Belirlenmesi. Tarla Bitkileri Merkez Araştırma Enstitüsü Dergisi, 26 (1): 24-30.

Çağlar Ö, Akten Ş 1994. Bazı Kışlık Ekmeklik Buğday Çeşit ve Hatlarında Verim, Bitki ve Tane Protein İlişkilerinin İncelenmesi. Tarla Bitkileri Kongresi, 25-29 Nisan 1994, İzmir.

Çağlar Ö, Öztürk A, Bulut S 2006. Bazı Ekmeklik Buğday Çeşitlerinin Erzurum Ovası Koşullarına Adaptasyonu. Atatürk Üniv. Zraat Fak. Dergisi, 37(1): 1-7.

Doğan Y, Kendal E 2012. Diyarbakır Koşullarında Bazı Ekmeklik Buğday (Triticum aestivum L.) Genotiplerinin Tane Verimi ve Bazı Kalite Özelliklerinin Belirlenmesi. YYÜ. Tar. Bil. Derg. 23(3): 199-208.
Doğan Y, Kendal E 2013. Diyarbakır Koşullarında Bazı Ekmeklik Buğday (Triticum aestivum L.) Genotiplerinin Tane Verimi ve Bazı Kalite Özelliklerinin Belirlenmesi. YYÜ Tarım Bilimleri Dergisi, 23 (3): 199-208.

Naneli İ, Sakin MA, Kıral AS 2015.Tokat-Kazova Şartlarında Bazı Ekmeklik Buğday (Triticum aestivum L.) Çeşitlerinin Verim ve Kalite Özelliklerinin Belirlenmesi. Gaziosmanpaşa Üniv. Ziraat Fak. Dergisi, 32 (1): 91-103.

Özen S, Akman Z 2015. Yozgat Ekolojik Koşullarında Bazı Ekmeklik Buğday Çeşitlerinin Verim ve Kalite Özelliklerinin Belirlenmesi. Süleyman Demirel Üniv. Ziraat Fak. Dergisi, 10 (1): 35-43.

Öztürk A, Akkaya A 1996. Kışlık Buğday Genotiplerinde Tane Verimi, Verim Unsurları ve Fenolojik Dönemler Üzerine Bir Araştırma. Atatürk Üniv. Zraat Fak. Dergisi, 27: 187-202.

Soylu S, Topal A, Sade B, Akgün N 1999. Konya Şartlarında Bazı Ekmeklik Buğday Çeşitlerinin Verim ve Verim Öğelerinin Belirlenmesi. S.Ü. Ziraat Fakültesi Derg., 13: 60-73.

Tunca ZŞ 2012. Bazı Buğday Çeşitlerinin Adaptasyon Kabiliyeti, Agronomik ve Fizyolojik Özelliklerinin Belirlenmesi. Eskişehir Osmangazi Üniversitesi, Fen Bilimleri Enstitüsü, Tarla Bitkileri Anabilim Dalı, Yüksek Lisans Tezi.

Wiegand CL, Gebermann AH, Cuellar JA 1981. Devolepment and Yield Of Hard Red Winter Wheats As Affected By Temperature. Crop Sci. 21: 95-101. 